\title{
Crossing the 100-publication milestone to celebrate the new year 2021
}

\author{
Thanh-Huyen T. Nguyen, Minh-Hoang Nguyen, Manh-Toan Ho \\ Centre for Interdisciplinary Social Research \\ Phenikaa University \\ Hanoi, January 1, 2021
}

As the year 2021 has just begun, it is time for us to look back to see what we have achieved so far. Last year, the year of 2020 , marked a special event for the Center for Interdisciplinary Social Research (ISR, Phenikaa University) as our research center passed the 100th publication milestone [1104].

Born on August 1, 2017, the research center has existed for 1249 days. For these 41 months, we have published 104 publications in many forms, including original research articles, editorial/viewpoint articles, data descriptors, review articles, books, book chapters, conference papers, well-recognized science blog posts, and even a software package. The share of each type of publication is given in Figure 1.

Figure 1. ISR's publications by types

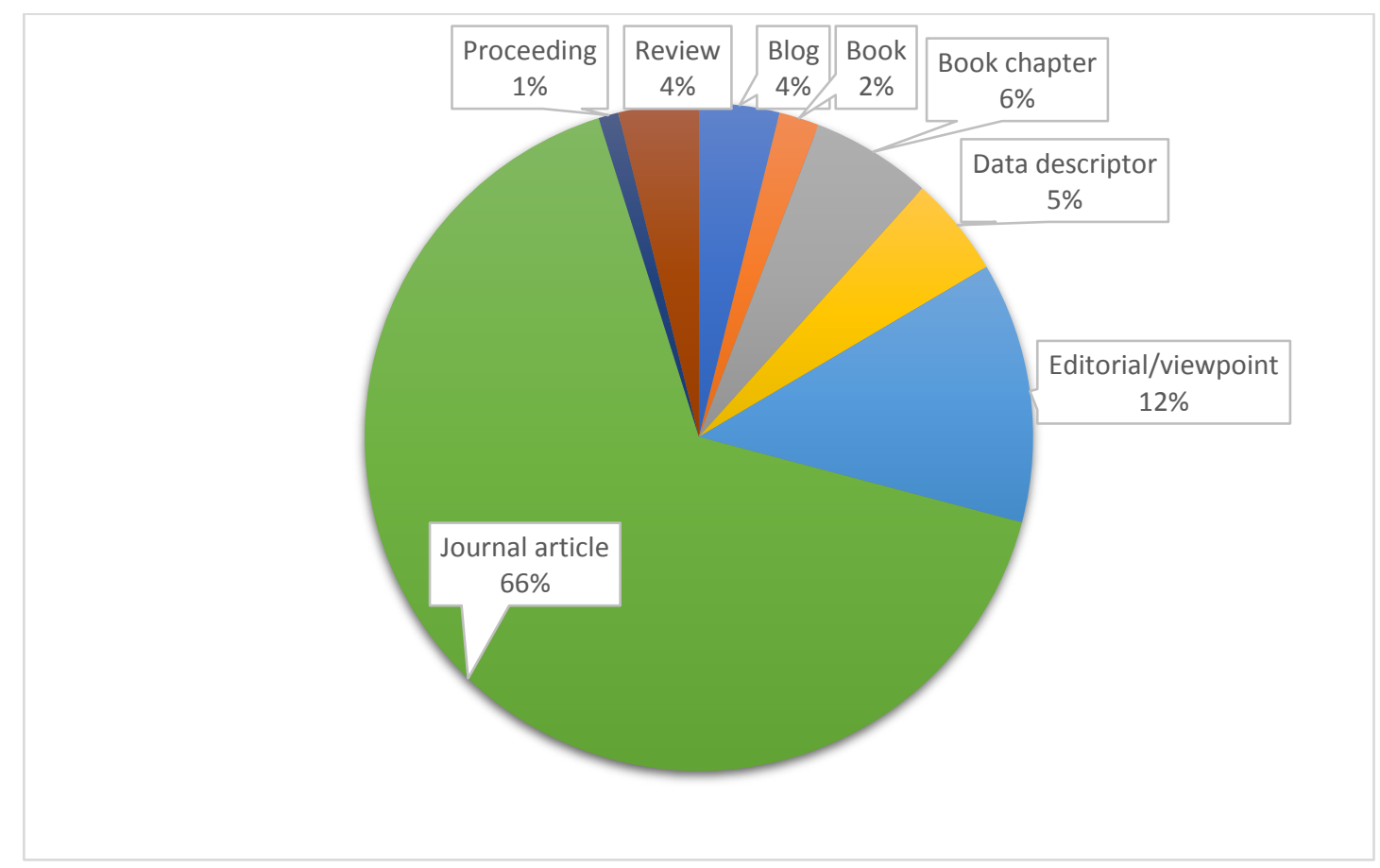

After the rigorous reviewing, revising process, and thousands of corresponding letters, 68 original research articles have finally found their homes for print in 35 journals of 21 publishers, such as Elsevier, Nature Research, Springer, and Oxford University Press, Taylor \& Francis. 
The second most popular type of publications from ISR is editorial and viewpoint, consisting of 13 publications in prestigious journals, like Nature, Nature Human Behavior, European Science Editing, etc. ISR has published two conference papers, both in the Proceedings of the XXIV World Congress of Philosophy. The proceedings belong to volumes published for the Beijing World Congress in 2018. Since 2017, ISR authors have contributed to well-recognized scientific blogs, once on Scientific Data Updates [7], twice on Behavioural and Social Sciences Community operated by Nature Research [58, 96], and once on London School of Economics and Political Science's well-known LSE Impact of Social Sciences [100]. Three books and six book chapters were released in 2019 and 2020. Among six book chapters, five are on scientometrics, and one is on entrepreneurial finance. Data descriptors account for $5 \%$ of the total production by ISR (5 pieces), published on either Scientific Data (Nature Research) or Data (MDPI). During the last two years, ISR members have also started writing review articles on Social Medicine issues (2 pieces) and Economics disciplines (2 pieces).

Notably, ISR researchers have obtained 12 publications with Nature Research (5 journal articles, 2 data descriptions, 3 blogs, and 3 viewpoints). In addition, in May 2019, our Bayesian analysis package for R-studio software was approved and now is available on CRAN (https://cran.rproject.org/package=bayesv) [105] after hectic days and nights. These accomplishments, as mentioned above, are not without failure. Just from estimating the last three years, we have received more than 300 rejections from various journals and publishers among more than ten disciplines, e.g., Economics \& Finance, Education, Environmental Science, Political Science, Gender Studies, Computer Sciences, Library and Information Sciences, Business \& Management, Public Health, etc.

Figure 2. ISR's publication by fields

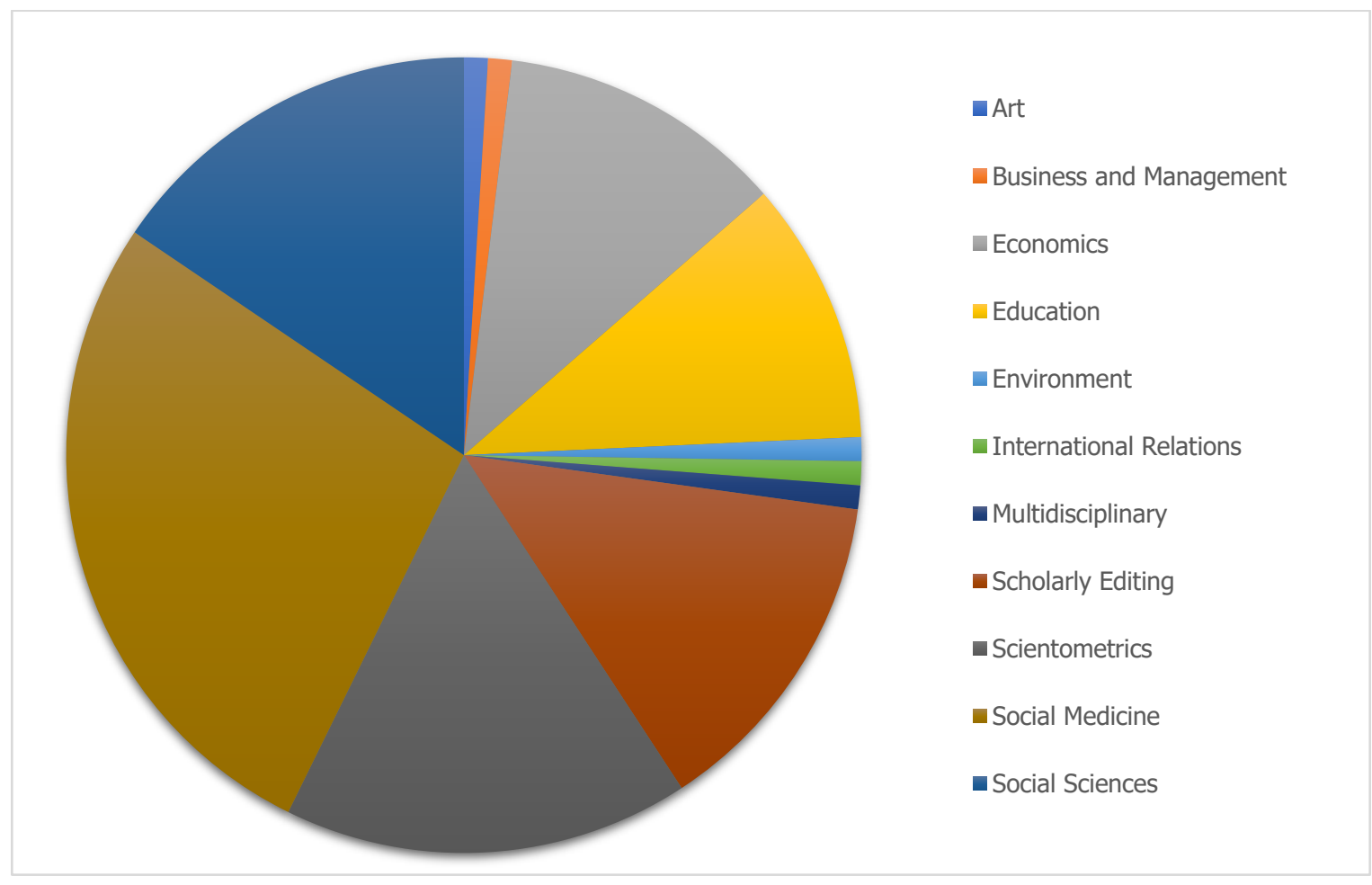

As our name suggested, ISR researchers have worked on various topics, from economics and education to art and scientometrics (Figure 2). It should be noted that some papers can be classified into several topics simultaneously, but we only selected the most related topic for presentation. Perhaps, that is why the team has collaborated with scientists who specialized in multiple disciplines. 
We have worked with scientists from many prestigious institutions, such as John Hopkins University (USA), Science Po (France), National University of Singapore (Singapore), Charles University (Czech), Foreign Trade University (Vietnam), Vietnam-Germany Hospital (Vietnam), Ritsumeikan Asia Pacific University (Japan).

In more than three years, ISR research has contributed to society and the scientific community. For example, a group of scientists from the University of Miami used Vuong's elaboration on the growing public distrust in science [8] to explain why Americans believed in Zika conspiracy theory [106]. Our Vietnamese social scientists' database was referred to as an example to build open databases for the public $[107,108]$.

This year, the Indian University Grants Commission (Figure 3) referred to the blog post on LSE Impact Blog [100] in their guidance document of good academic practices [109]. Amidst the COVID19 , our timely work on the role of media and scientific communication to fight against the pandemic in Vietnam provides useful perspectives for research in multiple disciplines (e.g., health policy, education, economics) [77]. It was used to advocate for strong communication as an effective strategy against COVID-19 and strengthen public trust [110]. Another paper using our paper on COVID-19 also agreed that good policy is a must to control the spread of COVID-19 [111].

\section{Figure 3. Guidance Document of Indian University Grants Commission [109]}

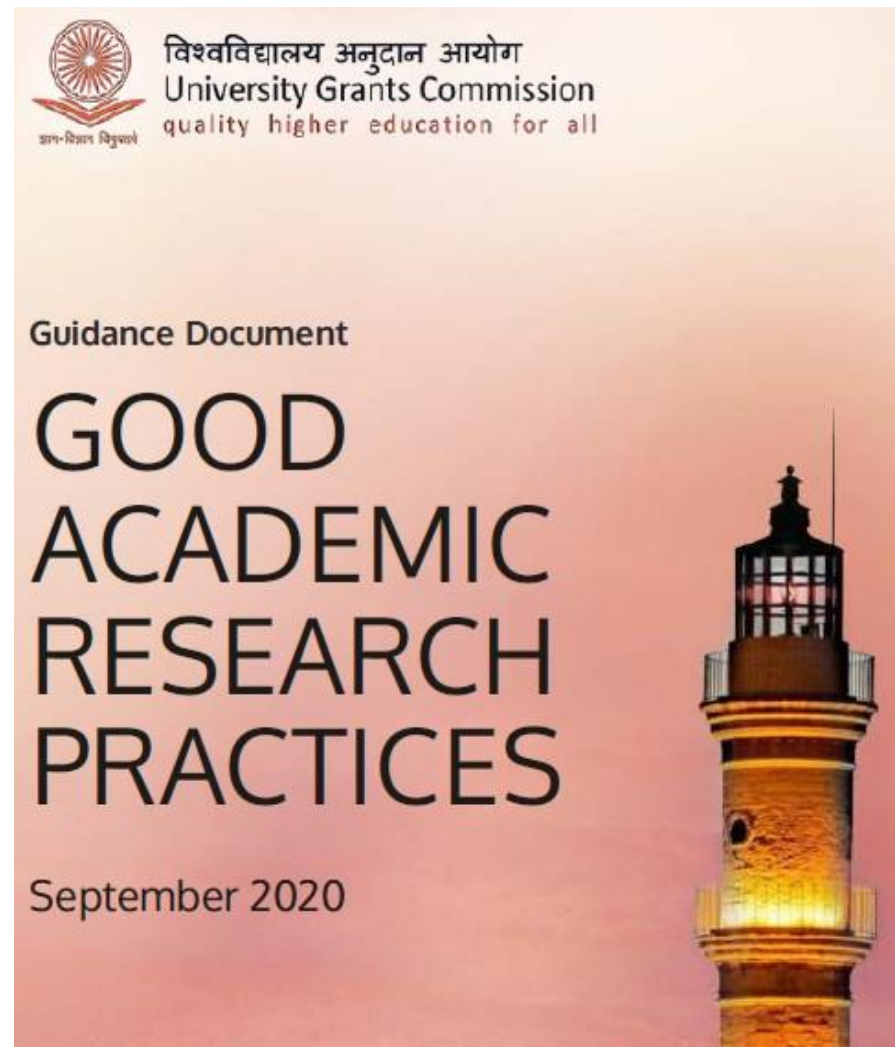

On improving the representation of science, especially during COVID-19, a publication from the Royal Society of Canada referred to the viewpoint article on Nature [86], which proposed four steps for a more transparent mechanism to retract paper [112]. This initiative got the attention of scientists from many countries, thus was translated into four languages: Chinese [113], Spanish [115], German [116], and Japanese [114]. 
Figure 4. Note of the Royal Society of Canada [112]

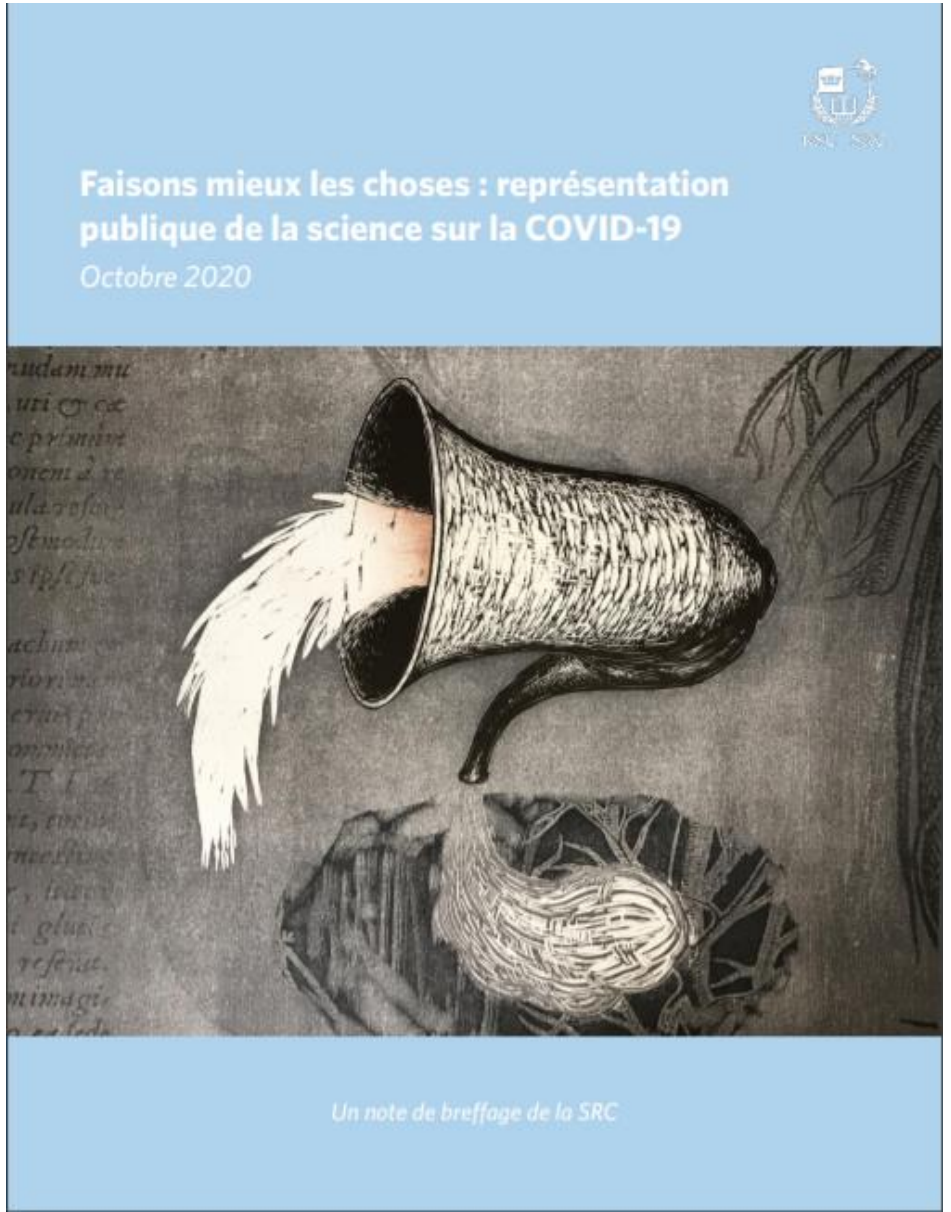

The impact was not limited to ISR's publications but also our past works. In 2019, the DeVane Lectures hosted by Yale University, with the topic "Power and Politics in Today's World," used a 2014 working paper written by ISR founder [17]. Stratfor Worldview-the leading news agency in geopoliticspublished a shorter version of [17] on their platform in 2014 [18].

Figure 5. 2019 DeVane Lectures at Yale University 


\section{Yale}

\section{DeVane Lectures: "Power and Politics in Today's World”}

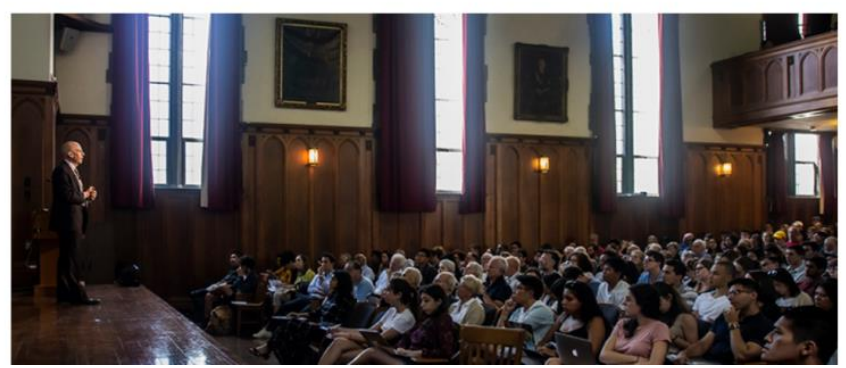

'Power and Politics' in the media

Yale News: Public invited to Professor Shapiro's 'Power and Politics' DeVane Lectures

YaleNews: Reflecting on Bretton Woods with Yale political scientist lan Shapire

The New York Times: Frances McCal Rosenbluth and lan Shapiro's tivate "Responsible Parties." and the test of U.K. democracy amidst Brexit

In the last few years, we have also worked on two major scientific databases: SSHPA and Scimath. SSHPA is a public database recording scientific profiles of Vietnam social researchers. This project was provided with a national research grant by the National Foundation for Science and Technology Development of Vietnam (NAFOSTED) for basic science research in the social sciences and humanities. The infrastructure of SSHPA was described in Scientific Data [17]. Datasets extracted from the SSHPA database were the backbones in our publications [24, 85, 88]. These original research articles investigated various aspects of social science research in Vietnam, such as productivity, collaboration pattern, and adoption of open-access publishing.

The Scimath Database is the product of the project $A$ Database of Vietnam Mathematics, which was initiated under the direction of Prof. Ngo Bao Chau (Vietnam Institute for Advanced Studies in Mathematics - VIASM) and Dr. Vuong Quan Hoang (ISR, AIDSL). In 2020, ISR also had meetings with Vietnam Institute for Advanced Studies in Mathematics to report the progress of the Scimath database. The product is a preliminary report on the development of mathematics in Vietnam since the first international publication by Le Van Thiem in 1945 [118]. We expect to introduce this database to the scientific community and the public in the near future.

Figure 6. First meeting with VIASM to report the progress of Scimath database 


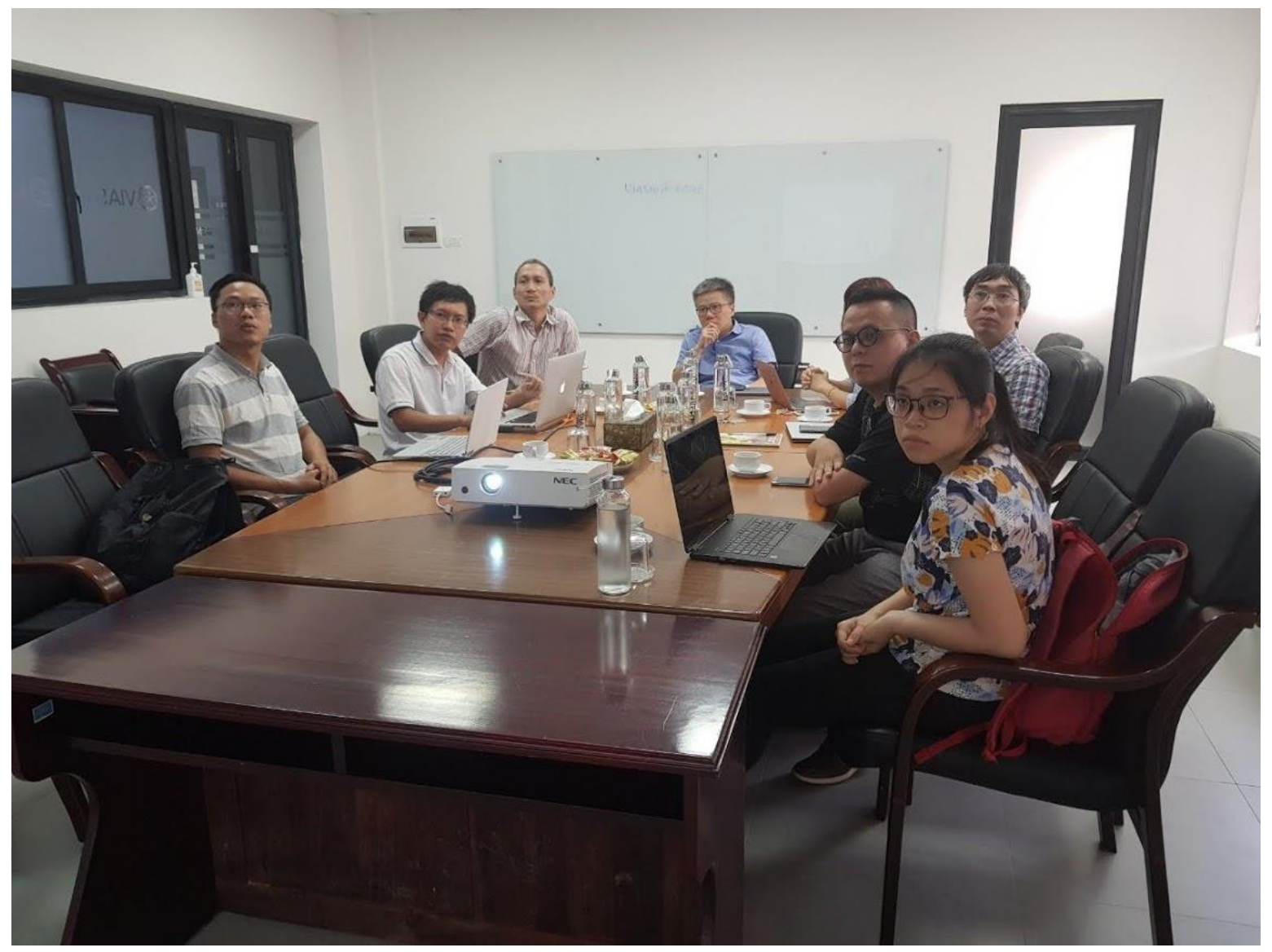

The $100^{\text {th }}$ publication is indeed special. Looking back upon those achievements in the last 1249 days, we are motivated to work even harder. We know that plenty of plans and new ideas still wait for us in the future.

Our publications are listed in the References section that follows.

And we all wish you a Happy New Year!

\section{References}

1. Vuong, Q. H. (2017). Learning to love the reviewer. European Science Editing, 43(4), 83.

2. Ho, T. M., Nguyen, H. V., Vuong, T. T., Dam, Q. M., Pham, H. H., \& Vuong, Q. H. (2017). Exploring Vietnamese co-authorship patterns in social sciences with basic network measures of 20082017 Scopus data. F1000Research, 6, 1559.

3. Pekerti, A., Vuong, Q. H., Ho, T. M., \& Vuong, T. T. (2017). Health care payments in Vietnam: Patients' quagmire of caring for health versus economic destitution. International Journal of Environmental Research and Public Health, 14(10), 1118.

4. Vuong, Q. H., Ho, T. M., Vuong, T. T., Nguyen, H. V., Napier, N. K., \& Pham, H. H. (2017). Nemo solus satis sapit: Trends of research collaborations in the Vietnamese social sciences, observing 2008-2017 Scopus data. Publications, 5(4), 24. 
5. Vuong, Q. H., Vuong, T. T., Ho, T. M., \& Nguyen, H. V. (2017). Psychological and socio-economic factors affecting social sustainability through impacts on perceived health care quality and public health: The case of Vietnam. Sustainability, 9(8), 1456.

6. Vuong, Q. H. (2017). Survey data on Vietnamese propensity to attend periodic general health examinations. Scientific Data, 4(1), 1-10.

7. Vuong, Q. H. (2017). Open data, open review and open dialogue in making social sciences plausible. Nature: Scientific Data Updates. URL: <http://blogs.nature.com/scientificdata/2017/12/12/authors-corner-open-data-openreview-and-open-dialogue-in-making-social-sciences-plausible/>.

8. Vuong, Q. H. (2018). The (ir) rational consideration of the cost of science in transition economies. Nature Human Behaviour, 2(1), 5.

9. Vuong, Q. H. (2018). Sociodemographic factors influencing Vietnamese patient satisfaction with healthcare services and some meaningful empirical thresholds. Iranian Journal of Public Health, 47(1), 119.

10. Ho, T. M., Vuong, T. T., \& Vuong, Q. H. (2017). On the sustainability of co-authoring behaviors in Vietnamese social sciences: A preliminary analysis of network data. Sustainability, 9(11), 2142.

11. Vuong, T. T., Ho, T. M., Ho, T. M., \& Vuong, Q. H. (2018). The (in) significance of sociodemographic factors as possible determinants of Vietnamese social scientists' contributionadjusted productivity: Preliminary results from 2008-2017 Scopus data. Societies, 8(1), 3.

12. Ho, M. T., Nguyen, T. H. K., Ho, M. T., Vuong, T. T., \& Vuong, Q. H. (2018). To be human in the age of Industry 4.0: perspective from Vietnam. Proc. XXIV World Congress of Philosophy, Beijing 13-20 Aug. 2018. http://wcp2018.pku.edu.cn/yw/index.htm.

13. Vuong, Q. H., Ho, M. T., La, V. P., Vuong, T. T., Nguyen, T. H. K. (2018). How philosophy of social sciences can benefit from Bayesian statistics: Insights from a developing country. Proc. XXIV World Congress of Philosophy, Beijing 13-20 Aug. 2018. http://wcp2018.pku.edu.cn/yw/index.htm

14. Vuong, Q. H., Ho, T. M., Nguyen, H. K., \& Vuong, T. T. (2018). Healthcare consumers' sensitivity to costs: A reflection on behavioural economics from an emerging market. Palgrave Communications, 4(1), 1-10.

15. Tran, B. X., Pham, T. V., Ha, G. H., Ngo, A. T., Nguyen, L. H., Vu, T. T. M., ... \& Truong, N. T. (2018). A bibliometric analysis of the global research trend in child maltreatment. International Journal of Environmental Research and Public Health, 15(7), 1456.

16. Tran, B. X., Mai, H. T., Fleming, M., Do, H. N., Nguyen, T. M. T., Vuong, Q. H., ... \& Truong, N. T. (2018). Factors associated with substance use and sexual behavior among drug users in three mountainous provinces of Vietnam. International Journal of Environmental Research and Public Health, 15(9), 1885.

17. Vuong, Q. H., La, V. P., Vuong, T. T., Ho, M. T., Nguyen, H. K. T., Nguyen, V. H., ... \& Ho, M. T. (2018). An open database of productivity in Vietnam's social sciences and humanities for public use. Scientific Data, 5, 180188.

18. Vuong, Q. H., Ho, M. T., Vuong, T. T., Tran, K., \& Ho, M. T. (2018). "Paintings can be forged, but not feeling": Vietnamese art-market, fraud, and value. Arts, 7(4), 62.

19. Vuong, Q. H., Hoang, A. D., Vuong, T. T., La, V. P., \& Ho, M. T. (2018). Factors associated with the regularity of physical exercises as a means of improving the public health system in Vietnam. Sustainability, 10(11), 3828.

20. Khuat, T. H., Do, T. T., Nguyen, V. A. T., Vu, X. T., Nguyen, P. T. T., Tran, K., ... \& Vuong, Q. H. (2018). The dark side of female HIV patient care: Sexual and reproductive health risks in preand post-clinical treatments. Journal of Clinical Medicine, 7(11), 402.

21. Nguyen, T. M. T., Tran, B. X., Fleming, M., Pham, M. D., Nguyen, L. T., Le, H. T., ... \& Vuong, Q. $\mathrm{H}$. (2018). Methadone maintenance treatment reduces the vulnerability of drug users on HIV/AIDS in Vietnamese remote settings: Assessing the changes in HIV knowledge, perceived 
risk, and testing uptake after a 12-month follow-up. International Journal of Environmental Research and Public Health, 15(11), 2567.

22. Vuong, Q. H., Bui, Q. K., La, V. P., Vuong, T. T., Nguyen, V. H. T., Ho, M. T., ... \& Ho, M. T. (2018). Cultural additivity: behavioural insights from the interaction of Confucianism, Buddhism and Taoism in folktales. Palgrave Communications, 4(1), 143.

23. Tran, B. X., Nguyen, Q. N., Dang, A. K., Vu, G. T., Hoang, V. Q., La, P. V., ... \& Le, H. T. (2018). Acceptability of and willingness to pay for using a smartphone-based vaccination application in a Vietnamese cohort. Patient Preference and Adherence, 12, 2583.

24. Vuong, Q. H., Napier, N. K., Ho, T. M., Nguyen, V. H., Vuong, T. T., Pham, H. H., \& Nguyen, H. K. T. (2019). Effects of work environment and collaboration on research productivity in Vietnamese social sciences: evidence from 2008 to 2017 Scopus data. Studies in Higher Education, 44(12), 2132-2147.

25. Ho, M. T., \& Vuong, Q. H. (2019). The values and challenges of 'openness' in addressing the reproducibility crisis and regaining public trust in social sciences and humanities. European Science Editing, 45(1), 14-17.

26. Nguyen, T. M. T., Tran, B. X., Fleming, M., Pham, M. D., Nguyen, L. T., Nguyen, A. L. T., ... \& Ho, M. T. (2019). HIV knowledge and risk behaviors among drug users in three Vietnamese mountainous provinces. Substance Abuse Treatment, Prevention, and Policy, 14(1), 1-8.

27. Nguyen, V. A. T., Nguyen, N. Q. H., Khuat, T. H., Nguyen, P. T. T., Do, T. T., Vu, X. T., ... \& Vuong, Q. H. (2019). Righting the Misperceptions of Men Having Sex with Men: A Pre-Requisite for Protecting and Understanding Gender Incongruence in Vietnam. Journal of Clinical Medicine, 8(1), 105.

28. Vuong, Q. H., Nghiem, K. C. P., La, V. P., Vuong, T. T., Ho, M. T., Tran, K., ... \& Ho, M. T. (2019). Sex differences and psychological factors associated with general health examinations participation: Results from a Vietnamese cross-section dataset. Sustainability, 11(2), 514.

29. Tran, B. X., Nguyen, L. H., Vu, G. T., Le, H. T., Nguyen, H. D., Hoang, V. Q., ... \& Nguyen, H. L. T. (2019). Online peer influences are associated with receptiveness of youths: The case of Shisha in Vietnam. Children and Youth Services Review, 99, 18-22.

30. Vuong, Q. H., Ho, M. T., Vuong, T. T., La, V. P., Ho, M. T., Nghiem, K. C. P., ... \& Ho, C. S. (2019). Artificial intelligence vs. natural stupidity: Evaluating Al readiness for the Vietnamese medical information system. Journal of Clinical Medicine, 8(2), 168.

31. Hoang, C. D., Tran, B. X., Pham, M. D., Nguyen, L. H., Do, H. N., Vuong, Q. H., ... \& Pham, H. Q. (2019). HIV-and AIDS-related knowledge and attitude of residents in border regions of Vietnam. Harm Reduction Journal, 16(1), 11.

32. Vuong, Q. H. (2019). SciRev: an initiative for improving peer review transparency. European Science Editing, 45(1), 20.

33. Vuong, Q. H. (2019). Computational entrepreneurship: From economic complexities to interdisciplinary research. Problems and Perspectives in Management, 17(1), 117-129.

34. Pham, H. H., Lai, S. L., \& Vuong, Q. H. (2019). The Role of Subjective Task Value in Forming Satisfaction and Loyalty Among Vietnamese International Students: A Structural Equation Model. The Asia-Pacific Education Researcher, 28(5), 399-409.

35. Tran, B. X., Vu, G. T., Ha, G. H., Vuong, Q. H., Ho, M. T., Vuong, T. T., ... \& Latkin, C. A. (2019). Global evolution of research in artificial intelligence in health and medicine: a bibliometric study. Journal of Clinical Medicine, 8(3), 360.

36. Nguyen, M. H., Serik, M., Vuong, T. T., \& Ho, M. T. (2019). Internationalization and its discontents: Help-seeking behaviors of students in a multicultural environment regarding acculturative stress and depression. Sustainability, 11(7), 1865.

37. Vuong, Q. H., Le, A. V., La, V. P., Vuong, T. T., Do, T. H., Vuong, H. M., ... \& Ho, M. T. (2019). A Dataset of Vietnamese junior high school students' reading preferences and habits. Data, 4(2), 49. 
38. Vu, T. H., Nguyen, V. D., Ho, M. T., \& Vuong, Q. H. (2019). Determinants of Vietnamese listed firm performance: Competition, wage, CEO, firm size, age, and international trade. Journal of Risk and Financial Management, 12(2), 62.

39. Ho, M. T., La, V. P., Nguyen, M. H., Vuong, T. T., Nghiem, K. C. P., Tran, T., \& Vuong, Q. H. (2019). Health Care, medical insurance, and economic destitution: A dataset of 1042 stories. Data, 4(2), 57.

40. Pham, K. T. H., Nguyen, L. H., Vuong, Q. H., Ho, M. T., Vuong, T. T., Vu, G. T., ... \& Ho, R. (2019). Health inequality between migrant and Non-Migrant workers in an industrial zone of Vietnam. International Journal of Environmental Research and Public Health, 16(9), 1502.

41. Vuong, Q. H., Ho, T. M., \& La, V. P. (2019). 'Stargazing' and p-hacking behaviours in social sciences: some insights from a developing country. European Science Editing, 45(2), 56-57.

42. Tran, B. X., Vu, G. T., Pham, K. T. H., Vuong, Q. H., Ho, M. T., Vuong, T. T., ... \& Ho, R. (2019). Depressive Symptoms among industrial workers in Vietnam and correlated factors: A multi-site survey. International Journal of Environmental Research and Public Health, 16(9), 1642.

43. Le, A. V., Do, D. L., Pham, D. Q., Hoang, P. H., Duong, T. H., Nguyen, H. N., ... \& Vuong, Q. H. (2019). Exploration of youth's digital competencies: a dataset in the educational context of Vietnam. Data, 4(2), 69.

44. Thao, T. T. P., Thai, L. D., Thanh, H. T., Tran, T., \& Vuong, Q. H. (2019). Mobile learning for highschool mathematics as a path to better sustainability in a fast-changing society: An exploratory study from Vietnam. Problems and Perspectives in Management, 17(2), 392-403.

45. Vuong, Q. H., Vuong, T. T., \& Ho, M. T. (2019). The 'same bed, different dreams' of Vietnam and China: how (mis)trust could make or break it. European Journal of East Asian Studies, 18(1), 93-128.

46. Ho, H. H., Vu, T. H., Dao, N. T., Ho, M. T., \& Vuong, Q. H. (2019). When the Poor Buy the Rich: New Evidence on Wealth Effects of Cross-Border Acquisitions. Journal of Risk and Financial Management, 12(2), 102.

47. Nguyen, V. H. T., Vuong, T. T., Ho, M. T., \& Vuong, Q. H. (2019). The new politics of debt in the transition economy of Vietnam. Austrian Journal of South-East Asian Studies, 12(1), 91-110.

48. Tran, B. X., Fleming, M., Nguyen, T. M. T., Vu, G. T., Vuong, Q. H., Ho, M. T., ... \& Latkin, C. (2019). Changes in substance abuse and HIV risk behaviors over 12-month methadone maintenance treatment among Vietnamese patients in mountainous provinces. International Journal of Environmental Research and Public Health, 16(13), 2422.

49. Nguyen, T. D., \& Ho, M. T. (2019). People as the Roots (of the State): Democratic Elements in the Politics of Traditional Vietnamese Confucianism. Journal of Nationalism, Memory \& Language Politics, 13(1), 90-110.

50. Vuong, Q. H. (2019). The harsh world of publishing in emerging regions and implications for editors and publishers: The case of Vietnam. Learned Publishing, 32(4), 314-324.

51. Tran, T., Le, T. T. H., Nguyen, T. T., Pham, A. G., Vu, T. H., Nguyen, M. H., ... \& Vuong, Q. H. (2019). The relationship between birth order, sex, home scholarly culture and youths' reading practices in promoting lifelong learning for sustainable development in Vietnam. Sustainability, 11(16), 4389.

52. Nguyen, M. H., Ho, M. T., Nguyen, Q. Y. T., \& Vuong, Q. H. (2019). A dataset of students' mental health and help-seeking behaviors in a multicultural environment. Data, 4(3), 124.

53. Vuong, Q. H., Bui, Q. K., La, V. P., Vuong, T. T., Ho, M. T., Nguyen, H. K. T., ... \& Ho, M. T. (2019). Cultural evolution in Vietnam's early 20th century: A Bayesian networks analysis of Hanoi Franco-Chinese house designs. Social Sciences \& Humanities Open, 1(1), 100001.

54. Le, T. A., Pham, D. T., Quek, T. T., Vu, G. T., Hoang, C. L., Tran, T. T., ... \& Tran, B. X. (2019). Polysubstance use among patients enrolling in methadone maintenance treatment program in a Vietnam province with drug-driven HIV epidemic. International Journal of Environmental Research and Public Health, 16(18), 3277. 
55. Le, T. T. H., Tran, T., Trinh, T. P. T., Nguyen, C. T., Nguyen, T. P. T., Vuong, T. T., ... \& Nguyen, M. H. (2019). Reading habits, socioeconomic conditions, occupational aspiration and academic achievement in Vietnamese junior high school students. Sustainability, 11(18), 5113.

56. Le, T. A., Le, M. Q. T., Dang, A. D., Dang, A. K., Nguyen, C. T., Pham, H. Q., ... \& Tran, T. H. (2019). Multi-level predictors of psychological problems among methadone maintenance treatment patients in different types of settings in Vietnam. Substance Abuse Treatment, Prevention, and Policy, 14(1), 39.

57. Vuong, Q. H. (2019). Breaking barriers in publishing demands a proactive attitude. Nature Human Behaviour, 3(10), 1034-1034.

58. Ho, M. T., Vuong, T. T., Nguyen, M. H., \& Ho, T. (2019). To Walk on the Penrose Stairs of Science. Behavioural and Social Sciences. URL: https://socialsciences.nature.com/ channels/2140-is-it-publish-or-perish/posts/54541-to-walk-on-the-penrose-stairs-of-

\section{science>.}

59. Vuong, Q. H., Vu, T. H., Doan, Q. H., \& Ho, M. T. (2019). Determinants of Vietnamese footwear exporting firms' market selection: A multinomial logistic analysis of panel data. Heliyon, 5(10), e02582.

60. Vuong, Q. H., \& Tran, T. (Ed.) (2019). The Vietnamese Social Sciences at a Fork in the Road. Warsaw, Poland: De Gruyter (Edition: Sciendo). DOI: 10.2478/9783110686081.

61. Nguyen, T. T., La, V. P., Ho, M. T., \& Nguyen, H. K. T. (2019). Scientific publishing: a slow but steady rise. In: Vuong, Q. H., \& Tran, T. (Eds.) The Vietnamese Social Sciences at a Fork in the Road (pp. 33-51). Warsaw, Poland: De Gruyter. DOI: 10.2478/9783110686081-007.

62. Le, T. H. T., Pham, H. H., La, V. P., \& Vuong, Q. H. (2019). The faster-growing fields. In: Vuong, Q. H., \& Tran, T. (Eds.) The Vietnamese Social Sciences at a Fork in the Road (pp. 52-79). Warsaw, Poland: De Gruyter. DOI: 10.2478/9783110686081-008.

63. Doan, X. H., Nguyen, P. T. T., La, V. P., \& Nguyen, H. K. T. (2019). Researchers who lead the trends. In: Vuong, Q. H., \& Tran, T. (Eds.) The Vietnamese Social Sciences at a Fork in the Road (pp. 98-120). Warsaw, Poland: De Gruyter. DOI: 10.2478/9783110686081-010.

64. Nguyen, H. K. T., Nguyen, T. H. T., Ho, M. T., Ho, M. T., \& Vuong, Q. H. (2019). Scientific publishing: the point of no return. In: Vuong, Q. H., \& Tran, T. (Eds.) The Vietnamese Social Sciences at a Fork in the Road (pp. 143-162). Warsaw, Poland: De Gruyter. DOI: 10.2478/9783110686081-012.

65. Ho, M. T., Hoang, K. L., Nguyen, M. H., \& Ho, M. T. (2019). The emerging business of science in Vietnam. In: Vuong, Q. H., \& Tran, T. (Eds.) The Vietnamese Social Sciences at a Fork in the Road (pp. 163-177). Warsaw, Poland: De Gruyter. DOI: 10.2478/9783110686081-013.

66. Vuong, Q. H., \& Tran, T. (2019). Closing remarks. In: Vuong, Q. H., \& Tran, T. (Eds.) The Vietnamese Social Sciences at a Fork in the Road (pp. 178-180). Warsaw, Poland: De Gruyter. DOI: 10.2478/9783110686081-014.

67. Vuong, Q. H., Ho, M. T., Nguyen, H. K. T., \& Nguyen, M. H. (2019). The trilemma of sustainable industrial growth: Evidence from a piloting OECD's Green city. Palgrave Communications, 5(1), 156.

68. Vuong, Q. H. (2020). The limitations of retraction notices and the heroic acts of authors who correct the scholarly record: An analysis of retractions of papers published from 1975 to 2019. Learned Publishing, 33(2), 119-130.

69. Vuong, Q. H. (2020). Plan S, self-publishing, and addressing unreasonable risks of society publishing. Learned Publishing, 33(1), 64-68.

70. Tran, T., Hoang, K. L., La, V. P., Ho, M. T., \& Vuong, Q. H. (2020). Scrambling for higher metrics in the Journal Impact Factor bubble period: a real-world problem in science management and its implications. Problems and Perspectives in Management, 18(1), 48-56.

71. Ngo, C. Q., Vu, G. V., Phan, P. T., Chu, H. T., Doan, L. P. T., Duong, A. T., ... \& Ha, G. H. (2020). Passive Smoking Exposure and Perceived Health Status in Children Seeking Pediatric Care 
Services at a Vietnamese Tertiary Hospital. International Journal of Environmental Research and Public Health, 17(4), 1188.

72. Nguyen, M. H., Ho, M. T., La, V. P., Nguyen, Q. Y. T., Ho, M. T., Vuong, T. T., ... \& Vuong, Q. H. (2020). A Scientometric Study on Depression among University Students in East Asia: Research and System Insufficiencies?. Sustainability, 12(4), 1498.

73. Vuong, Q. H., La, V. P., Ho, M. T., Vuong, T. T., \& Ho, M. T. (2020). Characteristics of retracted articles based on retraction data from online sources through February 2019. Science Editing, 7(1), 34-44.

74. Vuong, Q. H. (2020). The rise of preprints and their value in social sciences and humanities. Science Editing, 7(1), 70-72.

75. Vuong, Q. H., Le, A. V., La, V. P., Hoang, P. H., \& Ho, M. T. (2020). Making social sciences more scientific: Literature review by structured data. MethodsX, 7, 100818.

76. Tran, B. X., Moir, M., Nguyen, T. M. T., Do, H. N., Vu, G. T., Dang, A. K., ... \& Van Dam, N. (2020). Changes in quality of life and its associated factors among illicit drug users in Vietnamese mountainous provinces: a 12-month follow-up study. Substance Abuse Treatment, Prevention, and Policy, 15(1), 1-8.

77. La, V. P., Pham, T. H., Ho, M. T., Nguyen, M. H., P Nguyen, K. L., Vuong, T. T., ... \& Vuong, Q. H. (2020). Policy response, social media and science journalism for the sustainability of the public health system amid the COVID-19 outbreak: The Vietnam lessons. Sustainability, 12(7), 2931.

78. Vuong, Q. H., La, V. P., Vuong, T. T., Hoang, P. H., Ho, M. T., \& Ho, M. T. (2020). Multi-faceted insights of entrepreneurship facing a fast-growing economy: A literature review. Open Economics, 3(1), 25-41.

79. Vuong, Q. H., La, V. P., Vuong, T. T., Nguyen, H. K. T., Ho, M. T., \& Ho, M. T. (2020). What have Vietnamese scholars learned from researching entrepreneurship? A systematic review. Heliyon, 6(4), e03808.

80. Vuong, Q. H., La, V. P., Nguyen, M. H., Ho, M. T., Ho, M. T., \& Mantello, P. (2020). Improving Bayesian statistics understanding in the age of Big Data with the bayesvl R package. Software Impacts, 4, 100016.

81. Tran, T., Ho, M. T., Pham, T. H., Nguyen, M. H., Nguyen, K. L. P., Vuong, T. T., ... \& La, V. P. (2020). How digital natives learn and thrive in the digital age: Evidence from an emerging economy. Sustainability, 12(9), 3819.

82. Vuong, Q. H., Ho, M. T., Nguyen, H. K. T., Vuong, T. T., Tran, T., Hoang, K. L., ... \& La, V. P. (2020). On how religions could accidentally incite lies and violence: Folktales as a cultural transmitter. Palgrave Communications, 6(1), 82.

83. Vuong, Q. H., La, V. P., Nguyen, M. H., Ho, M. T., Tran, T., \& Ho, M. T. (2020). Bayesian analysis for social data: A step-by-step protocol and interpretation. MethodsX, 7, 100924.

84. Giang, T. L., Vo, D. T., \& Vuong, Q. H. (2020). COVID-19: A Relook at Healthcare Systems and Aged Populations. Sustainability, 12(10), 4200.

85. Ho, M. T., Vuong, T. T., Pham, T. H., Luong, A. P., Nguyen, T. N., \& Vuong, Q. H. (2020). The Internal Capability of Vietnam Social Sciences and Humanities: A Perspective from the 20082019 Dataset. Publications, 8(2), 32.

86. Vuong, Q. H. (2020). Reform retractions to make them more transparent. Nature, 582(7811), 149.

87. Pham, T. H., Ho, M. T., Vuong, T. T., Nguyen, M. C., \& Vuong, Q. H. (2020). Entrepreneurial Finance: Insights from English Language Training Market in Vietnam. Journal of Risk and Financial Management, 13(5), 96.

88. Vuong, T. T., Ho, M. T., Nguyen, M. H., Nguyen, T. H. T., Nguyen, T. D., Nguyen, T. L., ... \& Vuong, Q. H. (2020). Adopting open access in the social sciences and humanities: evidence from a developing nation. Heliyon, 6(7), e04522. 
89. Hoang, A. D., Pham, H. H., Nguyen, Y. C., Vuong, Q. H., Dam, M. Q., Tran, T., \& Nguyen, T. T. (2020). Introducing a tool to gauge curriculum quality under Sustainable Development Goal 4: The case of primary schools in Vietnam. International Review of Education, 66(4), 457-485.

90. Vuong, Q. H., La, V. P., Ho, M. T., Trang, V. T., \& Ho, M. T. (2020). Identifying the moral-practical gaps in corporate social responsibility missions of Vietnamese firms: an event-based analysis of sustainability feasibility. Corporate Social Responsibility and Environmental Management, 27, EarlyView, doi:10.1002/csr.2029.

91. Ho, M. T., La, V. P., Nguyen, M. H., Pham, T. H., Vuong, T. T., Vuong, H. M., ... \& Vuong, Q. H. (2020). An analytical view on STEM education and outcomes: Examples of the social gap and gender disparity in Vietnam. Children and Youth Services Review, 119, 105650.

92. Vuong, Q. H., \& Ho, M. T. (2020). Rethinking editorial management and productivity in the COVID-19 pandemic. European Science Editing, 46, e56541.

93. Vuong, Q. H. (2020). An Unprecedented Time for Entrepreneurial Finance upon the Arrival of Industry 4.0. Journal of Risk and Financial Management, 13(10), 224.

94. Nguyen, T. T. H., Pham, H. H., Vuong, Q. H., Cao, Q. T., Dinh, V. H., \& Nguyen, D. D. (2020). The adoption of international publishing within Vietnamese academia from 1986 to 2020: A review. Learned Publishing, EarlyView, doi: 10.1002/leap.1340.

95. Nguyen, H. K. \& Ho, T. M. (2020). Vietnam's COVID-19 Strategy: Mobilizing Public Compliance Via Accurate and Credible Communications. ISEAS Perspective, 69, 1-15.

96. Vuong, Q. H., La, V. P., Vuong, T. T., \& Ho, M. T. (2020). Earth Hour in Vietnam: a perspective from the electricity industry. Nature: Behavioural \& Social Sciences. Available from: https://go.nature.com/3eGzl6Y.

97. Vuong, Q. H. (Ed.). (2020). Entrepreneurial Finance at the Dawn of Industry 4.0. Basel, Switzerland: MDPI AG. DOI:10.3390/books978-3-03943-598-2

98. Vuong, Q. H., Pham, H. (2020). Accelerating social sciences reach a fork in the road. University World News. Retrieved from https://www.universityworldnews.com/ post.php?story $=20201118123527565$

99. Vuong, Q. H. (2020). ¿Cómo retractarse en ciencia?. Investigación y Ciencia, No 530 (Noviembre 2020). URL: https://www.investigacionyciencia.es/revistas/investigacion-yciencia/grandes-hitos-y-prximos-retos-de-la-ciencia-811/cmo-retractarse-en-ciencia-19145

100. Vuong, Q. H. (2020). Retractions: the good, the bad, and the ugly. What researchers stand to gain from taking more care to understand errors in the scientific record. LSE Impact of Social Sciences. Retrieved from: https://blogs.Ise.ac.uk/impactofsocialsciences/2020/02/20/ retractions-the-good-the-bad-and-the-ugly-what-researchers-stand-to-gain-from-taking-morecare-to-understand-errors-in-the-scientific-record/

101. Nguyen, M. H., Pham, T. H., Ho, M. T., Nguyen, H. T. T., \& Vuong, Q. H. (2020). On the social and conceptual structure of the 50-year research landscape in entrepreneurial finance. SN Business \& Economics, 1(1), 1-29.

102. Vuong, Q. H. (2021). From children's literature to sustainability science, and young scientists for a more sustainable Earth. Journal of Sustainability Education, 24: in-press.

103. Ho, M. T., Progler, J., \& Vuong, Q. H. (2021). Anatomy of contemporary Vietnamese satirical cartoons: Political communication and representation of systemic corruption. Asian Studies Review, 44, forthcoming.

104. Vuong, Q. H., Bui, A. T., La, V. P., Nguyen, M. H., Pham, H. H., Pham, T. H., Vu, T. H., Vuong, T. T., \& Ho, M. T. (2021). Mirror, mirror on the wall: Is economics the fairest of them all? An investigation into the social sciences and humanities in Vietnam. Research Evaluation, 30, inpress, DOI:10.1093/reseval/rvaa036.

105. La, V. P., \& Vuong, Q. H. (2019). bayesvl: Visually learning the graphical structure of Bayesian networks and performing MCMC with 'Stan'. The Comprehensive R Archive Network (CRAN). https://cran.r-project.org/package=bayesvl 
106. Klofstad, C. A., Uscinski, J. E., Connolly, J. M., \& West, J. P. (2019). What drives people to believe in Zika conspiracy theories?. Palgrave Communications, 5(1), 36. doi:10.1057/s41599-0190243-8

107. Li, J., Yin, Y., Fortunato, S., \& Wang, D. (2019). A dataset of publication records for Nobel laureates. Scientific Data, 6(1), 1-10.

108. Li, J., Yin, Y., Fortunato, S., \& Wang, D. (2020). Scientific elite revisited: patterns of productivity, collaboration, authorship and impact. Journal of the Royal Society Interface, 17(165), 20200135.

109. Patwardhan B., Desai A., Chourasia A, Nag S., Bhatnagar R. (2020). Guidance Document: Good Academic Research Practices. New Delhi: University Grants Commission. Retrieved from: https://www.ugc.ac.in/ebook/UGC_GARP_2020_Good\%20Academic\%20Research\%20Practi ces.pdf.

110. Marianne, U. P., Paula, M. L. (2020). Trust in Public Health Is Essential Amid the COVID-19 Pandemic. Journal of Hospital Medicine, 7, 431-433.

111. Oehmke, J. F., Moss, C. B., Singh, L. N., Oehmke, T. B., Post, L. A. (2020). Dynamic Panel Surveillance of COVID-19 Transmission in the United States to Inform Health Policy: Observational Statistical Study. Journal of Medical Internet Research, 22(10), e21955

112. Tania, B., Timothy, C., Jonathan, K., Vardit, R., (2020) Faisons mieux les choses : représentation publique de la science sur la COVID-19. Société royale du Canada. Retrieved from: $\quad$ https://rsc-src.ca/fr/covid-19-policy-briefing/faisons-mieux-les-chosesrepr\%C3\%A9sentation-publique-de-la-science-sur-la-covid.

113. Quan-Hoang Vuong. (2020). 論文撤回を改革して透明性を高めよ. Nature ダイジェスト, 17( 8), doi:10.1038/ndigest.2020.200818.

114. 李晨阳, 徐竞然 (2020). 要撤稿? 请交代清楚这 4 点！中国科学报社 (June 9). http://news.sciencenet.cn/htmlnews/2020/6/441196.shtm

115. Michael Springer (2020). Selbstkontrolle mit kleinen Fehlern. Spektrum der Wissenschaft (October 26). *URL: https://www.spektrum.de/kolumne/luecken-im-peer-reviewprozess/1771644

116. Yale University. (2019). 2019 DeVane Lectures: "Power and Politics in Today's World". Yale University web page. https://communications.yale.edu/2019-devane-lectures-power-andpolitics-todays-world

117. Vuong, Quan-Hoang. (2014). Vietnam's political economy in transition (1986-2016). StratforThe Hub: International Perspectives. https://worldview.stratfor.com/article/vietnamspolitical-economy-transition-1986-2016

118. Chau, N. B., Hoang, V. Q., Phuong, L. V., Hoa, L. T., Ha, L. M., Giang, T. T. T., ... \& Trung, T. (2020). The 80-year development of Vietnam mathematical research: Preliminary insights from the SciMath database on mathematicians, their works and their networks. arXiv preprint arXiv:2011.09328. 